\title{
ASSESSMENT OF THE MONITORING OF AN INDUSTRIAL WASTE LANDFILL
}

\author{
OCENA MONITORINGU \\ SKŁADOWISKA ODPADÓW PRZEMYSŁOWYCH
}

\begin{abstract}
Industrial waste deposited in landfills poses a threat to the environment and can cause its deterioration. The physical and chemical processes that result in the formation of a number of harmful substances occur in the mass of stored waste. When released to the environment these compounds can be dangerous to all its elements, especially to groundwater. The monitoring of landfill impact plays an important role in assessing the state of the environment. It allows us to follow what changes take place in the waste bed itself, and in particular elements of the environment. On the basis of long-term monitoring studies (conducted in the years 1995-2016), the quality of groundwater around the industrial waste landfill in Zgierz was determined and its impact on the environment was characterized. The quality of conducted monitoring was assessed in relation to the current regulations. Analysis of the results of groundwater quality tests confirms that the industrial landfill in the operational phase due to a number of applied security measures has not contributed to the deterioration of groundwater quality. In the post-operational phase, groundwater contamination is observed, and consequently irreversible changes occur in the environment. The negative impact of the landfill can be due to the disruption of sealing layers and elution of pollutants from the waste by rainwater. The landfill site monitoring plays a key role in assessing causal relationships occurring between the state of the landfill and elements of the environment in its vicinity.
\end{abstract}

Keywords: waste landfill, industrial waste, environmental impact

\section{Introduction}

An integral part of all human activities is waste production. The development of civilization and technological progress observed in recent years caused a significant rise of the amount of waste produced and an increase of its diversity. At present, over 140 million $\mathrm{Mg}$ (tonnes) of waste is produced each year in Poland, with $90 \%$ of the total waste being generated in production processes. Its main sources are mining, energy and metallurgical industries.

Huge amounts of industrial waste produced each year and its specific nature (the percentage of hazardous waste) are not neutral to the environment and represent a serious threat to its components [2]. Danger associated with environmental pollution

\footnotetext{
${ }^{1}$ Faculty of Process and Environmental Engineering, Lodz University of Technology, ul. Wólczańska 175, 90-924 Łódź, Poland, phone +48 426313779

*Corresponding author: monika.janas@edu.p.lodz.pl
} 
occurs in all phases of waste management, i.e. during production, collection, transport, utilization, and especially during disposal. Therefore, in recent years special emphasis has been put on the rational waste management as one of the aspects of environmental protection. Among the methods of industrial waste disposal we can distinguish recycling, incineration, mechanical processing of industrial waste and final disposal [3]. Currently, the incineration of hazardous waste, due to the decomposition of harmful substances into simpler inorganic compounds, is the most effective method of disposal. However, combustion processes require extensive investments in infrastructure [4,5]. The costs of construction and operation of incineration plants are by far the highest among all disposal methods. Landfill sites are the last element of waste utilization and management, and they still receive considerable amounts of waste, including industrial waste, which is not suitable for further use. The most important threats to the environment are related to physical and chemical processes and changes occurring in the mass of disposed waste. Products of decomposition contain a number of harmful compounds as well as solid and liquid substances which in most cases get into the environment and can pose a risk to both surface and underground water and soil. The functioning landfills also deteriorate landscape amenities of the land in which they are situated [6-8].

Monitoring provides constant control of proper landfill functioning. It enables the identification and observation of the migration of pollutants deposited in a landfill. The time which determines the rate and intensity of physicochemical changes occurring in landfills should be taken into account when evaluating the environmental impact of such facilities [9].

Despite numerous studies addressing the threat of industrial waste landfills, there are still many questions about their negative environmental impacts. This is due to the variation in the composition of waste collected, technological solutions used and a number of external factors that determine the way and extent of the spread of pollutants. Accordingly, in order to determine the impact of a landfill on the environment, it is necessary to consider each case separately $[6,8]$.

The purpose of the research was to assess the impact of the industrial waste landfill on the environment, with particular emphasis on the quality of groundwater in the years 1995-2016. The quality of monitoring was evaluated taking into account the current regulations [10].

\section{Landfill monitoring}

Inseparable from the problem of waste disposal is the monitoring of natural environment. In accordance with Article 124, items 4 and 5, of the Waste Act of 14 December 2012 [11], the landfill manager is obliged to monitor the landfill at the following phases:

$>$ pre-operation - the period from the date of obtaining the permit to use the landfill,

$>$ operation - the period from the date of obtaining the permit to use the landfill until the date of obtaining permission to close it,

$>$ post-operation - a period of 30 years from the date of obtaining the decision to close the landfill [11].

Detailed requirements on the scope, time, method and conditions of monitoring are set out in the Ordinance of the Minister of Environment on landfills of April 30, 2013 [10] Table 1. 
Range of indicator parameters and minimum frequency of their testing at particular phases of landfill operation [10]

\begin{tabular}{|c|c|c|c|c|}
\hline \multirow{2}{*}{ No. } & \multirow{2}{*}{ Indicator parameter } & \multicolumn{3}{|c|}{ Minimum frequency of testing } \\
\cline { 3 - 5 } & Pre-operation phase & Operation phase & Post-operation phase \\
\hline 1 & Surface water flow rate & Once & every 3 months & every 6 months \\
\hline 2 & Surface water composition & Once & every 3 months & every 6 months \\
\hline 3 & Leachate volume & None & once a month & every 6 months \\
\hline 4 & Leachate composition & None & every 3 months & every 6 months \\
\hline 5 & Groundwater level & Once & every 3 months & every 6 months \\
\hline 6 & Groundwater composition & Once & every 3 months & every 6 months \\
\hline 7 & Landfill gas emission & None & once a month & every 6 months \\
\hline 8 & Landfill gas composition & none & none a month & every 6 months \\
\hline 9 & $\begin{array}{c}\text { Efficiency of the landfill gas } \\
\text { discharge system }\end{array}$ & none & every 12 months \\
\hline 10 & Landfill subsidence & none & continuous & continuous \\
measurement & measurement \\
\hline 11 & Presence of mercury vapor & none & none & once a month \\
\hline 12 & $\begin{array}{c}\text { Visual inspection of mercury } \\
\text { disposal site and containers }\end{array}$ & none & none \\
\hline 13 & $\begin{array}{c}\text { Structure and composition of } \\
\text { waste mass }\end{array}$ & & & \\
\hline
\end{tabular}

Landfill site monitoring is a component of local monitoring, whose main task is to familiarize and follow the impact of identified or potential pollutants on groundwater and surface water and soil, to counteract the negative effects of their pollution. All regulations concerning the location, stage of construction, operation and closing of a landfill are intended to determine the safe and environmentally sound way of waste disposal, in particular to define technical conditions for prevention of the pollution of particular components of the environment $[11,12]$.

\section{Characteristics of the research area}

Groundwater monitoring was carried out in the industrial waste landfill excluded from operation located within the boundaries of the city of Zgierz in a special economic zone. In the south the landfill borders the forest area, in the north and east it is limited by regional and county roads and residential and service areas, and in the west it is adjacent to open areas used mainly for agricultural production.

The industrial waste landfill was built in 1995 for the needs of the former industrial plants, in the vicinity of three sedimentation tanks existing already since 1960 which collected process waste in the form of ash and plaster.

In the landfill the waste was disposed by a method enabling a maximum use of the landfill capacity. The landfill site occupies an area of 0.81 ha and has a geometric volume of $50,376 \mathrm{~m}^{3}$ limited by a dyke. Internal slopes are characterized by a decline of $1: 2.5$, the external ones by $1: 1.5$. Depending on the type, the wastes were disposed in containers, drums and metal barrels in an orderly manner in specified sectors of the landfill. Asbestos-containing wastes were stored in foil bags, big bags or pallets wrapped in foil, and the contaminated rubble and soil were directly deposited in bulk near the landfill slope. 


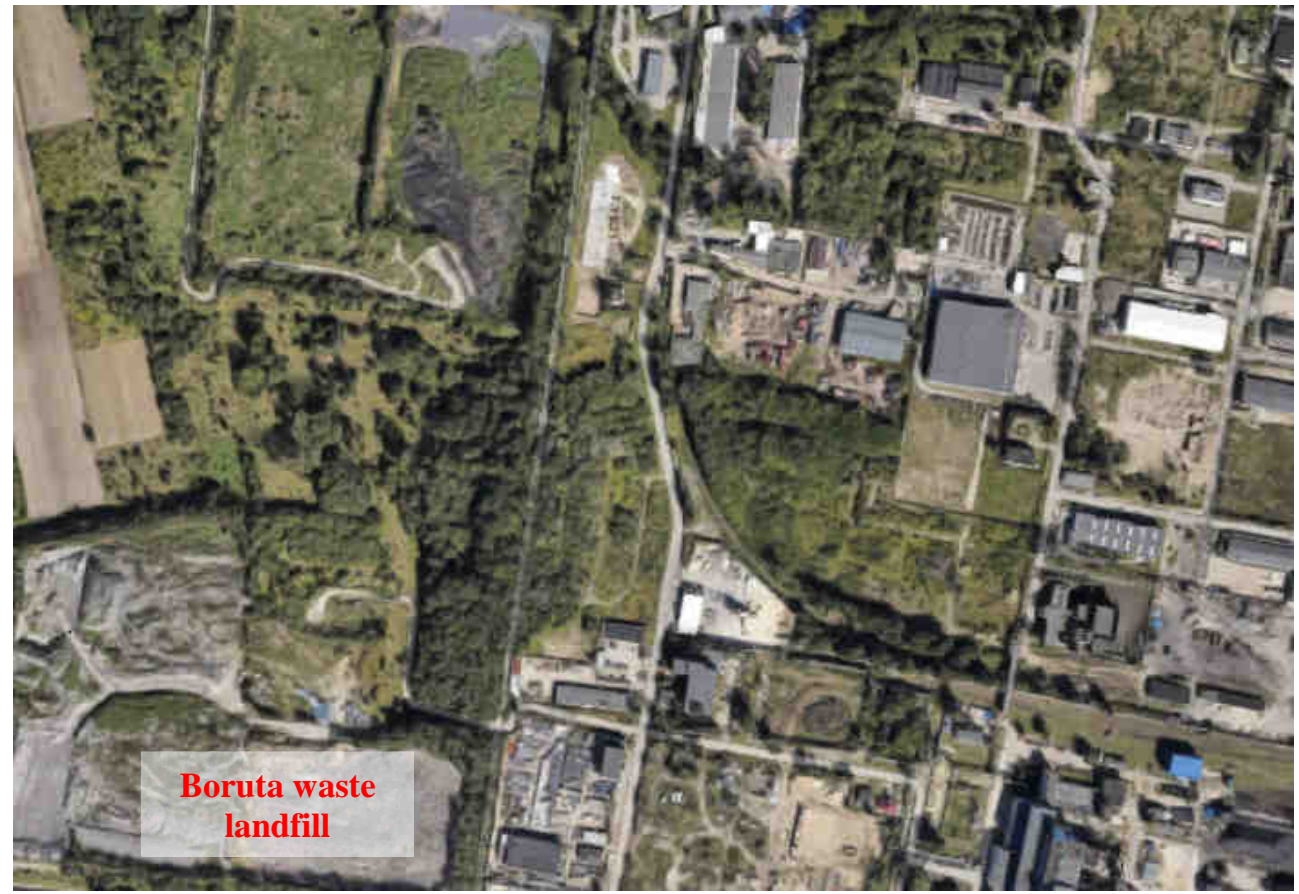

Fig. 1. Location of the Boruta industrial waste landfill in Zgierz

\section{Geological and hydrogeological conditions}

The geological structure of land in the landfill region is very complex. The landfill is located on the wing of the Lodz Cretaceous Basin, composed of limestone and marl from the Upper Cretaceous formations, under which about $450 \mathrm{~m}$ from the land surface there are strips of sandstone and Lower Cretaceous chalk. Cretaceous deposits are dominated by Tertiary deposits, mainly represented by clays with intercalations of quartz sand of different granulation. At the bottom, in the clay section there are admixtures of marls and chalky limestone. The Tertiary floor is corrugated and occurs at elevations of $110 \mathrm{~m}$ and the maximum thickness of these sediments is about $40 \mathrm{~m}$. The thickness of Quaternary cover sediments ranges from 8 to $134 \mathrm{~m}$ and these are mainly Pleistocene sediments of Central-Polish glaciation [13].

A specific geological structure (glaciotectonic deformations) of a large part of the area (edge zone of the Lodzkie Uplands, undulating moraine) determines the nature of groundwater in this area. Numerous cracks and outflows of aquifers cause that in the zone there is very little protection of groundwater against infiltration. Insulating layers have either a small thickness or only partially cover the outflow of aquifers [13].

According to the division into hydrogeological units, the analyzed area is located in the Mogilno-Lodz-Nida region. On the whole analyzed area, there is one, Quaternary water-bearing floor. The static water table of deeper layers of this level is less than $15 \mathrm{~m}$ from the land surface. This level is related to sand and gravel deposits of Pleistocene. It occurs at a variable depth of 10 to $50 \mathrm{~m}$ above ground level and has the character 
of a tense water table. The depths of the Quaternary wells range from 30 to $130 \mathrm{~m}$. The shallowest water with a free table, associated with young river sands occurs at the depth to 3-7 $\mathrm{m}$ within the river valley and land depression [13].

\section{Research methodology}

Monitoring of groundwater in the area of industrial waste landfill in Zgierz excluded from operation is based on S1-S9 piezometers with depths of 5.1 to $20.0 \mathrm{~m}$, the location of which is shown in Figure 2.

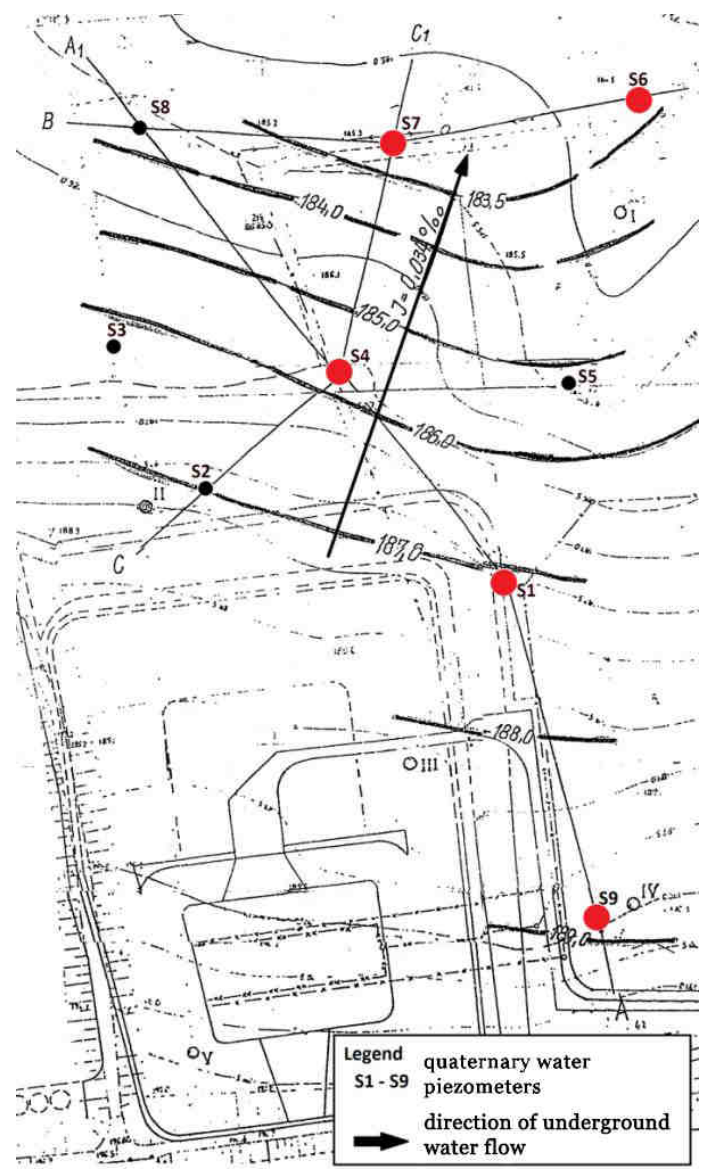

Fig. 2. Location of piezometers and directions of underground water flow at the waste landfill in Zgierz

These piezometers measure Quaternary water. The archived materials provide information on the chemical composition of water, among other things, in terms of specific electrolytic conductivity (SEC), chlorides, sulfates, heavy metals and many other pollutants. Measurement of electrolytic conductivity was performed using a conductivity meter. Heavy metals (lead, chromium, copper, mercury) were determined by inductively 
coupled atomic emission spectrometry in accordance with PN-EN ISO 11885:2009 [14], while sulfates and chlorides were determined by ion chromatography.

In the years 1995-2008 the monitoring of piezometers in the industrial waste landfill in Zgierz was carried out once a quarter. In 2008 monitoring of this landfill ended. It was only in the years 2015-2016 that water from piezometers was taken and analyzed in detail. In that period only 5 out of 9 piezometers were working (S1, S4, S6, S7 and S9).

In the study, in order to determine the environmental impact of the waste landfill in Zgierz over the years, an analysis based on a change in the composition of groundwater taken from five available piezometers was carried out. The results were compared with limit values for physicochemical elements of groundwater given in the Ordinance of the Minister of Environment of 21 December 2015 on the criteria and method of assessment of uniform parts of groundwater [15]. The results from 1995 to 2008 are the average of four measurements performed per year, while in 2008-2016 they are single measurements carried out under periodic monitoring.

\section{Results}

The aim of the study was to analyze and present changes in groundwater pollution indicators affected by changes occurring in the landfill. Assessment of the impact of closing industrial waste landfill in Zgierz on groundwater was based on water monitoring data. The results are shown in the diagrams below.

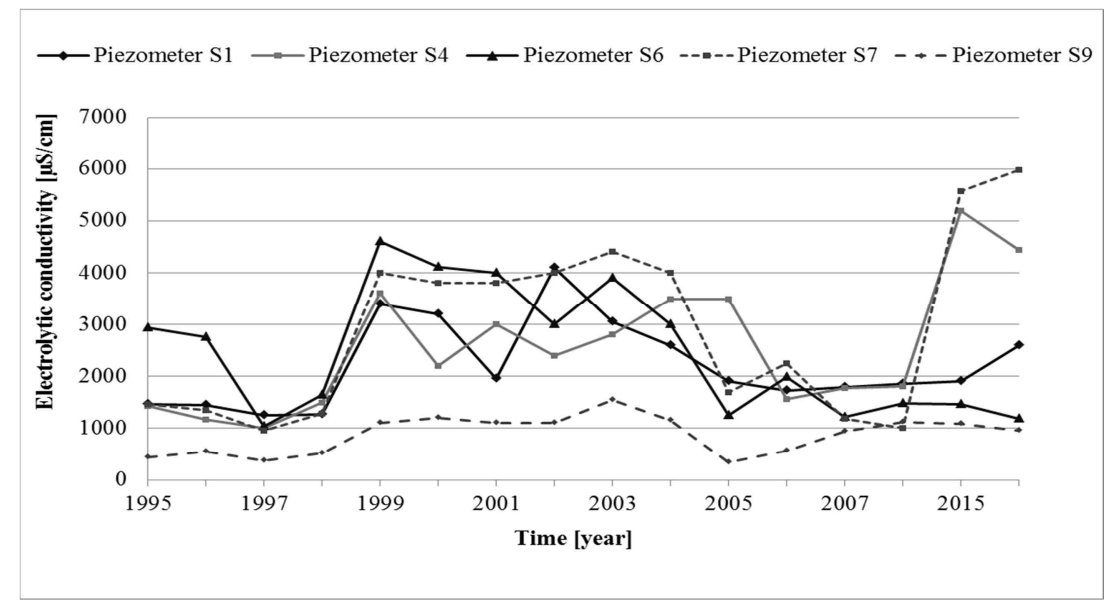

Fig. 3. Comparison of electrolytic conductivity in piezometers in the years 1995-2016

The first physicochemical indicator of water taken from piezometers was the specific electrolytic conductivity (SEC), referring to the amount of water mineralization [16-18]. In the period 1995 to 2016, in the waters of the S1, S4, S6 and S7 piezometers located directly near the landfill site, conductivity ranged from 1000 to $5900 \mu \mathrm{S} / \mathrm{cm}$. It is worth noting that values above $3000 \mu \mathrm{S} / \mathrm{cm}$ correspond to the $5^{\text {th }}$ class of groundwater quality and occurred only at a later stage of the landfill operation. Another trend is observed for water taken from the S9 piezometer, where the highest electrolytic conductivity in 2003 was 
$1550 \mu \mathrm{S} / \mathrm{cm}$ which corresponded to the $2^{\text {nd }}$ water quality class [15]. In the remaining period, after 2003, these values are significantly lower for the piezometer analyzed.

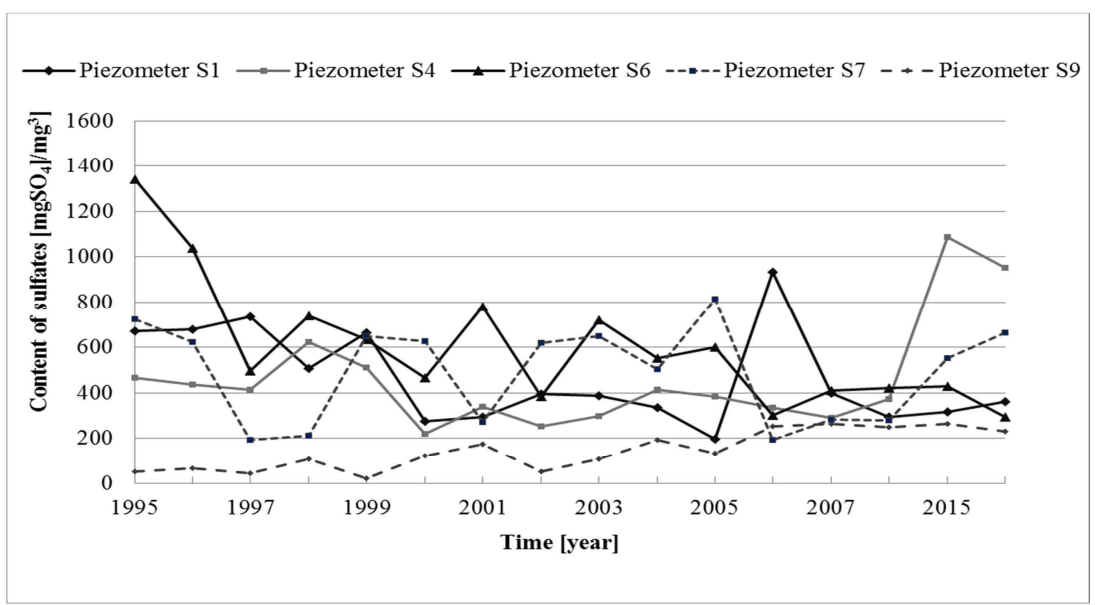

Fig. 4. Comparison of sulfates content in piezometers in the years 1995-2016

The content of sulfates in piezometric waters S1, S4, S6 and S7 in the years 1995-2016 was subject to considerable changes. Their content ranged between 200 and $1400 \mathrm{mg} \mathrm{SO}{ }_{4} / \mathrm{cm}^{3}$, thus exceeding the limit values for the $5^{\text {th }}$ water quality class [15]. Water from the S9 piezometer was characterized by greater purity and was the only one that met the requirements of the $3^{\text {rd }}$ class of groundwater. Over the years, we have observed a significant increase in sulfate content in groundwater from piezometers, which may be a result of direct penetration of pollutants into the water caused by leaching of waste [16].

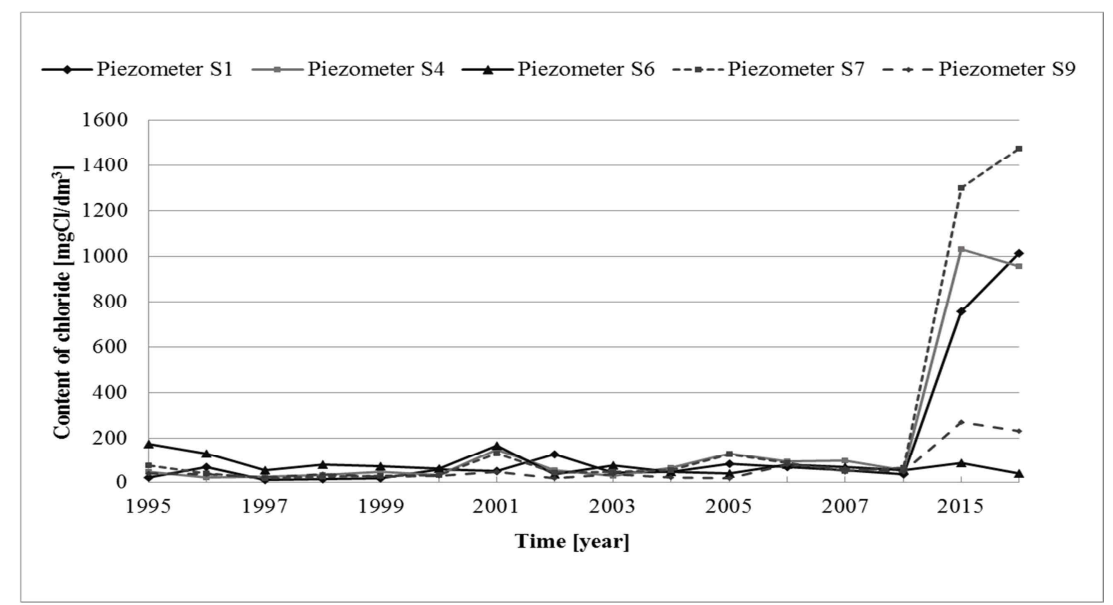

Fig. 5. Comparison of chloride content in piezometers in the years 1995-2016 
During the continuous monitoring period, chloride content in the studied water was at the level of $10-200 \mathrm{mg} \mathrm{Cl} / \mathrm{dm}^{3}$, thus corresponding to the $3^{\text {rd }}$ class of water quality [15]. Chlorine content in the analyzed water has increased considerably over the years, exceeding the limits set in the regulations.

Due to the role of water in the circulation of chemical components between different elements of the environment, the analysis covered also the contamination of water with trace elements, in particular with heavy metals. Metals in groundwater can occur due to penetration of pesticides and mineral fertilizers used in crop fields, but can also get from leachates from landfills and from industrial and municipal wastewater [16-17, 19]. The concentration of heavy metals in groundwater near the industrial waste landfill in Zgierz is shown in Figures 6-9.

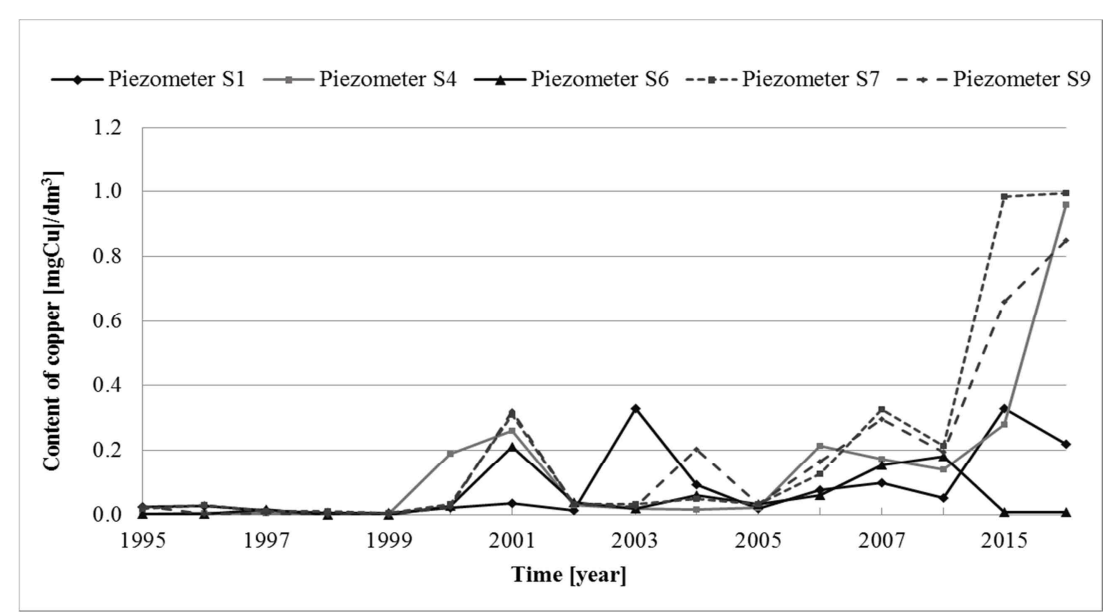

Fig. 6. Comparison of copper content in piezometers in the years 1995-2016

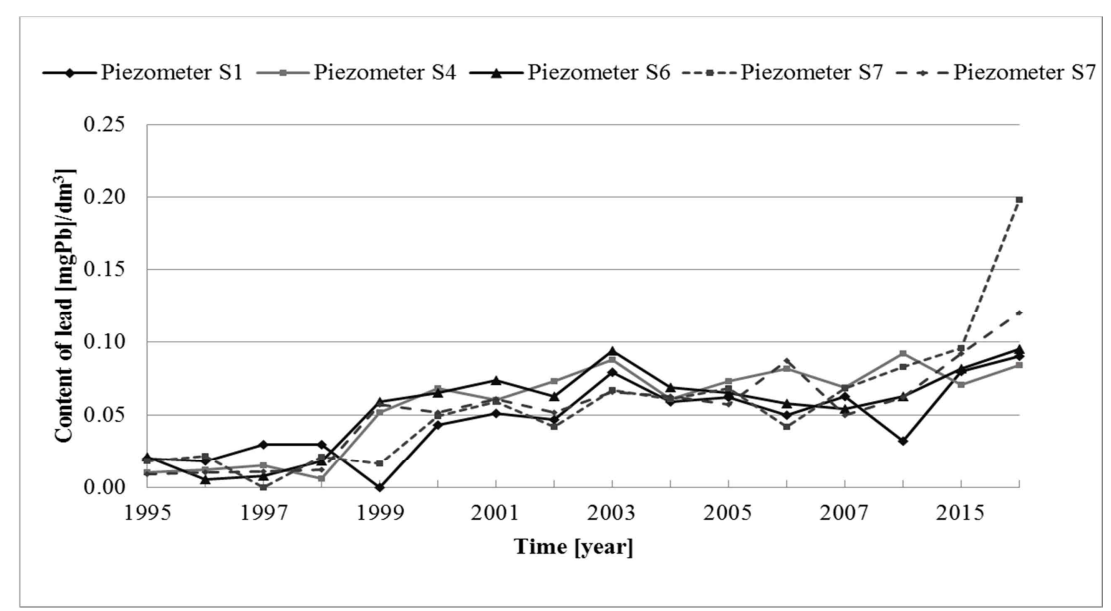

Fig. 7. Comparison of lead content in piezometers in the years 1995-2016 
In the initial period of operation, the concentration of copper in piezometric water was at a very low level of less than $0.02 \mathrm{mg} \mathrm{Cu} / \mathrm{dm}^{3}$, which corresponded to the second class of water quality [15]. With time we observe a gradual increase in copper content to $0.38 \mathrm{mg} \mathrm{Cu} / \mathrm{dm}^{3}$. Only in recent years the copper content has increased nearly fifty times compared to 1995. The increase in copper concentration can be attributed to changes occurring in the deposited waste, mainly from the electrical, pharmaceutical and dye industry.

When analyzing changes in lead concentration in the water from piezometers, we observe a trend similar to that characteristic of copper. In the initial phase of landfilling, lead concentration was low, below $0.03 \mathrm{mg} \mathrm{Pb} / \mathrm{dm}^{3}$ and gradually it increased to $0.2 \mathrm{mg} \mathrm{Pb} / \mathrm{dm}^{3}$ in 2016. The increase in the content of this metal may be associated with lead-containing waste.

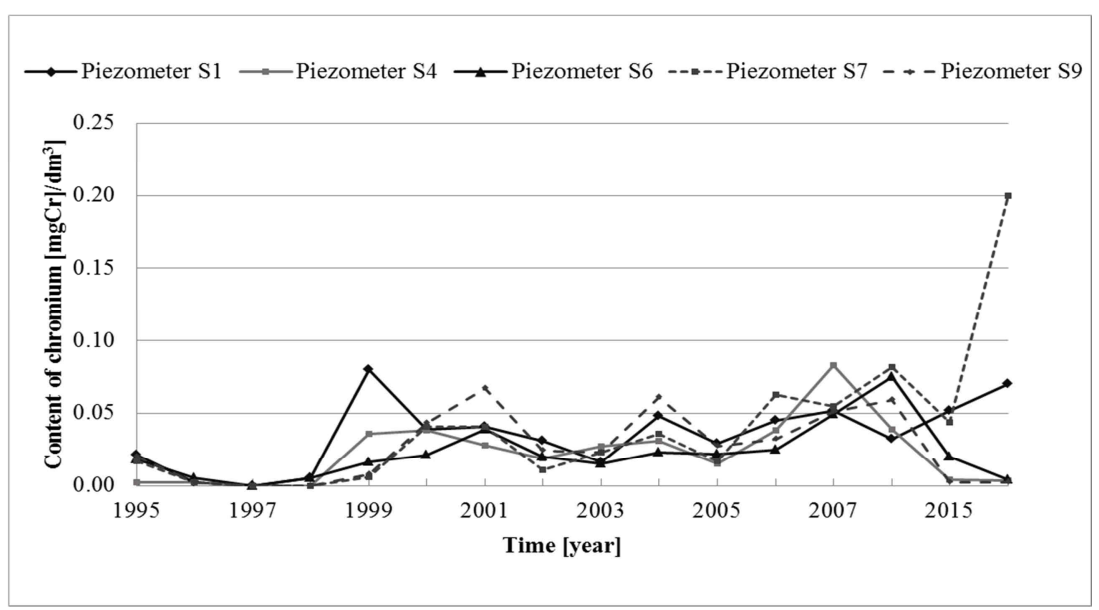

Fig. 8. Comparison of chromium content in piezometers in the years 1995-2016

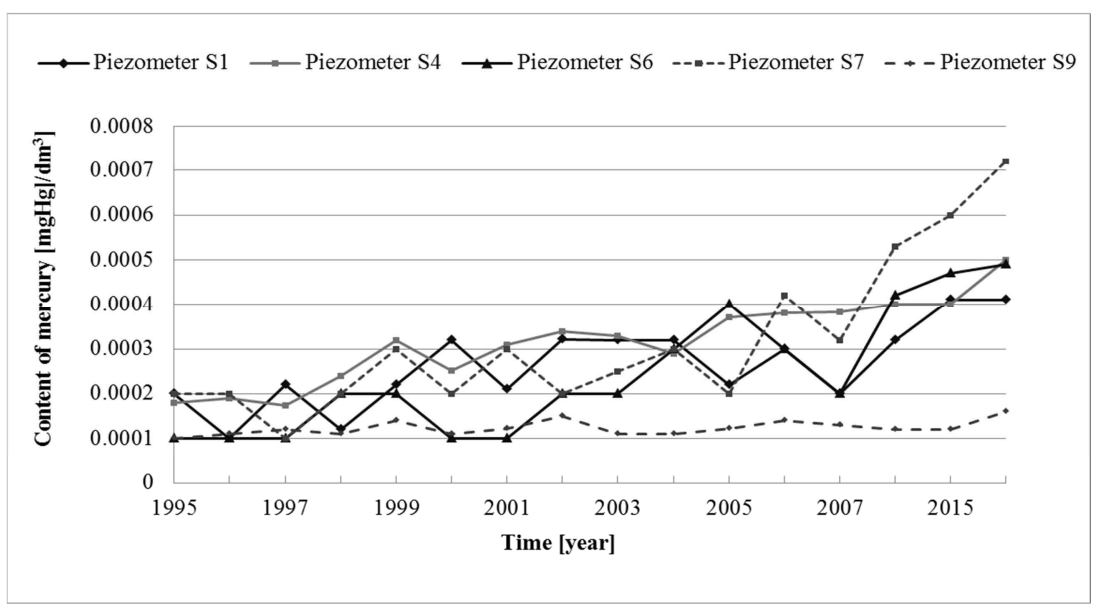

Fig. 9. Comparison of mercury content in piezometers in the years 1995-2016 
The same changes as in the case of lead and copper concentrations in groundwater are observed for chromium(VI). Initially, the concentration of chromium in the tested water was below $0.35 \mathrm{mg} \mathrm{Cr} / \mathrm{dm}^{3}$, since 1999 a gradual increase in the concentration has been observed, which in 2016 reached a level of $0.2 \mathrm{mg} \mathrm{Cr} / \mathrm{dm}^{3}$.

The mercury content in groundwater throughout the period covered by monitoring since 1995 to 2016 remained below the level for the $1^{\text {st }}$ class of groundwater quality.

According to the results presented, it can be concluded that the industrial waste landfill did not have a significant impact on the quality of groundwater in the initial period of operation. This is connected with appropriate sealing of the landfill bed which has been confirmed by proper monitoring of the site. After closing the landfill there was a significant deterioration in the groundwater quality, especially in the years 2015-2016.

\section{Conclusions}

The paper presents results of analyzes of water samples taken from piezometers located around the industrial waste landfill in Zgierz in the years 1995-2016. This analysis over the years proved to be extremely difficult due to the fact that monitoring was carried out by several different laboratories examining different indicators of water pollution.

Analysis of the results obtained for groundwater from the accessible piezometers shows that over the last few years the analyzed indicators increased significantly in this water. First of all, the increase was observed in the water from piezometers S1, S4, S6 and S7 which lie on the line of groundwater flow in the landfill area. Piezometer S9 is located on the side and at a distance from the flow line, hence the results of analyzes of groundwater from the piezometer can be regarded as a background. The results of analyzes of groundwater from piezometers S1, S4, S6 and S7 indicate clearly that after the end of the operation, significant groundwater contamination has occurred, as compared to the situation in the years 1995-2008. The observed increase in concentrations is mainly related to chlorides, sulfates, specific electrolytic conductivity and heavy metals. Since the landfill has already been closed for several years, this situation may be due to disrupting of the sealing layer and the elution of pollutants from the waste deposited in the landfill by rainwater. It is known from the archived data that part of the waste was deposited in metal barrels. Over time, the barrels could have corroded and pollutants they contained could have been released to the environment. Incorrect unloading and too high layers of barrels could damage the lining and cause leaching of dangerous substances into groundwater.

In recent years, the design, construction and protection of landfills has changed dramatically. Geomembranes effectively reduce discharge of these leachates into groundwater and surrounding soil. The scope of the monitoring was specified by numerous regulations defining its area as well as method and frequency. All these efforts are aimed at protecting the environment and, consequently, human health [18-20].

\section{References}

[1] Kacprzak M, Neczaj E, Fijałkowski K, Grobelak A, Grosser A, Worwag M, et al. Environ Res. 2017;156:39-46. DOI: 10.1016/j.envres.2017.03.010.

[2] Alumur S, Kara BY. Comput Oper Res. 2007; 34:1406-1423. DOI: 10.1016/j.cor.2005.06.012.

[3] Hamilton SF, Sproul TW, Sunding D, Zilberman D. J Environ Manage. 2013;66:337-346. DOI: 10.1016/j.jeem.2013.04.003.

[4] Emek E, Kara BY. Comput Oper Res. 2007; 34:1424-1441. DOI: 10.1016/j.cor.2005.06.011.

[5] Abaecherli ML, Capón-Garcia E, Szijjarto A, Hungerbühler K. Comput Chem Eng. 2017;104:241-258. DOI: 10.1016/j.compchemeng.2017.03.023. 
[6] Kurniawan TA, Lo W, Chang G, Sillanpaa MET. J Environ Monitor. 2010;12:2032-2047. DOI: $10.1039 / \mathrm{c} 0 \mathrm{em} 00076 \mathrm{k}$

[7] Boyer O, Hong TS, Pedram A, Yusuff RBM, Zulkifli N. J Appl Math. 2013;1-10. DOI: $10.1155 / 2013 / 435272$.

[8] Vasanthi P, Kaliappan S, Srinivasaraghaven R. Environ Monit Assess. 2008;143:227-238. DOI: 10.1007/s10661-007-9971-0.

[9] Yilmaz O, Kara BY, Yetis U. J Environ Manage. 2017; 203:720-731. DOI: 10.1016/j.jenvman.2016.06.015.

[10] Rozporządzenie Ministra Środowiska z dnia 30 kwietnia 2013 r. w sprawie składowisk odpadów. Dz.U. 2013, poz. 523. (Ordinance of the Minister of Environment of 30 April 2013 on landfill. J Laws 2013, item 523). http://prawo.sejm.gov.pl/isap.nsf/DocDetails.xsp?id=WDU20130000523.

[11] Ustawa z 14 grudnia 2012 o odpadach. Dz.U. 2017, poz. 785, 1566 (Polish Act of 14 December 2012 on waste. J Laws 2017. item 785, 1566). http://prawo.sejm.gov.pl/isap.nsf/DocDetails.xsp? $\mathrm{id}=\mathrm{wdu} 20130000021$.

[12] Öman CB, Junestedt C. Waste Manage. 2008;28:1876-1891. DOI: 10.1016/j.wasman.2007.06.018.

[13] Liszewski S, Plit F. Geography in Poland. Natural and Human Environment of Poland. A Geographical Overview. Warszawa: Polish Academy of Sciences, Stanisław Leszczycki Institute of Geography and Spatial Organization, Polish Geographical Society; 2006, 311-324. ISBN: 8387954683. http://rcin.org.pl/Content/36223/WA51_45533_r2006_Natural-human-enviro.pdf.

[14] PN-EN ISO 11885: 2007 Water quality - Determination of selected elements by means of optical emission spectrometry with inductively excited plasma (ICP-OES). https://www.iso.org/standard/36250.html.

[15] Rozporządzenie Ministra Środowiska z dnia 21 grudnia 2015 r. w sprawie kryteriów i sposobu oceny stanu jednolitych części wód podziemnych. Dz.U. 2016, poz. 85. (Ordinance of the Minister of Environment of 21 December 2015 on the criteria and method of assessment of uniform parts of groundwater (J Laws 2016, item 85). http://prawo.sejm.gov.pl/isap.nsf/DocDetails.xsp?id=WDU20160000085.

[16] Öman CB, Junestedt Ch. Waste Manage. 2008;28:1876-1891. DOI: 10.1016/j.wasman.2007.06.018.

[17] Kurniawan TA, Lo W, Chang G, Sillanpaa MET. J Environ Monitor. 2010;12:2032-2047. DOI: 10.1039/c0em00076k.

[18] Aderemi AO, Oriaku AV, Adewumi GA, Otitooju AA. Afr J Environ Sci Technol. 2011;5:9333-940. DOI: 10.5897/AJEST11.272.

[19] Butt TE, Javadi AA, Nunns MA, Beal CD. Sci Total Environ. 2016;269-570:815-829. DOI: 10.1016/j.scitotenv.2016.04.152.

[20] Zhao J, Huang L, Lee DH, Peng Q. Transport Res E-Log. 2016;88:52-75. DOI: 10.1016/j.tre.2016.02.002. 